九州大学学術情報リポジトリ

Kyushu University Institutional Repository

\title{
Purification and Some Properties of a
} Thermostable Protease, BSP2, Produced from Bacillus stearothermophilus No. 2

Ohta, Hiroki

Department of Food Science and Technology, Faculty of Agriculture, Kyushu University

Katoh, Tatsuo

Department of Food Science and Technology, Faculty of Agriculture, Kyushu University

Fujio, Yusaku

Department of Food Science and Technology, Faculty of Agriculture, Kyushu University

https://doi.org/10.5109/24088

出版情報: 九州大学大学院農学研究院紀要. 40 (1/2)，pp.9-17，1995-12. Kyushu University バージョン：

権利関係 : 


\title{
Purification and Some Properties of a Thermostable Protease, BSP2, Produced from Bacillus stearothermophilus No. 2
}

\author{
Hiroki Ohta, Tatsuo Katoh and Yusaku Fujio \\ Laboratory of Food Technology, Faculty of Agriculture, \\ Kyushu University, Fukuoka 812-81, Japan \\ (ReceinedMay8, 1.995)
}

\begin{abstract}
A thermophilic bacteria, Bacillusstearothermophilus No. 2 isolated from sewage sludge compost, was found to produce a thermostable neutral protease (BSP2). The BSP2 was purified from culture broth by fractionation with cold acetone and subsequent column chromatographies. The purified BSP2 gave a single band on SDS - PAGE and its molecular weight was estimated to be $35 \mathrm{kDa}$. The purified protease was optimally active at $\mathrm{pH} 7.5-8$ and showed stability at pH range of 6 to 11.5. The thermostability of the BSP2 was markedly improved under the presence of $\mathrm{Ca}^{-}\left(5 \mathrm{mM} \mathrm{CaCl}_{2}\right)$ with $60 \%$ residual activity after $80 \mathrm{~min}$ heattreatment at $90{ }^{\circ} \mathrm{C}$ and the optimum proteolytic activity was at $75{ }^{\circ} \mathrm{C}$ Its proteolytic activity was almost completely inactivated by metal chelaters such as EDTA and EGTA, and not by IAA or PMSF. The NH,-terminal amino acid sequence of the BSP2 showed high homology with those of thermostable neutral proteases from reffered Bacillus strains reported so far.
\end{abstract}

\section{INTRODUCTION}

Thermostable protease have been the subject of intensive research in the past years because of their potent application in various industrial processes as well as an interest in biochemical study. Considerable efforts are continuing to isolate new novel thermophiles as sources of thermostable proteases.

Thermolysin, which is well-known thermostable neutral protease produced by mesothermophilic Bacillus thermoproteolyticus, is of industrial important and specially has been studied in detail (Endo, 1962; Kester ans Matthews, 1977; Latt et al., 1969; Morihara and Tsuzuki, 1970; Stauffer, 1971). The primary and tertialy structures of thermolysin have been revealed (Titani et al., 1972; Matthews et al., 1972a; Mattews et al., 1972b). Recently, highly thermostable neutral proteases from Bacillus stearothermophilus and Bacillus caldolyticus have been reported and their primaly structures showed extremely high homology with those of thermolysin (Kubo et al., 1983b; Heinen and Heinen, 1972; Kubo and Imanaka, 1988; Van Der Burg et al., 1991). From our previous work, twelve strains of thermophilic bacteria were isolated from sewage sludge compost. Among them, Bacillus stearothermophilus No. 2 (strain No. 2) was found to produce an extracellular protease (Fujio and Kume, 1991).

This paper deals with the purification and the properties of the protease produced by Bacillus stearothermophilus No. 2 isolated from compost.

\section{MATERIALS AND METHODS}

Microorganism and cultivation media

Bacillus stearothennophilus No. 2 (strain No. 2), formerly isolated and identified 
(Fujio and Kume. 1991) was used in this study. The strain No. 2 mas incubat ed on agar slants (nutrient broth, $\mathrm{pH} 7.5$ ) at $60^{\circ} \mathrm{C}$ for $24 \mathrm{~h}$. The culture was inoculated in liquid medium $(0.5 \%$ yeast extract, $0.1 \%$ polypeptone, $0.1 \%$ casein peptone. $0.1 \%$ geratin, $0.1 \%$ $\mathrm{KH}_{\mathrm{PO}}$, dissolved with distilled water ans adjusted $\mathrm{pH}$ to 7.5$)$ in a $500 \mathrm{~m}$ mllask to prepare the inoculum for protease production. The cultivation was done $1160^{\circ} \mathrm{C}$ for 2 days. For protease production, $10 \%$ of the seed culture was inoculated into the medium composed of $1.5 \%$ Bacto peptone, $0.5 \%$ casein peptone, $0.3 \%$ yeast extract, $0.2 \% \mathrm{NaCl} .0 .1 \% \mathrm{KHPO}$ in distilled water with an initial $\mathrm{pH}$ of 7.5 . The cultivation was carried out at $60^{\circ} \mathrm{C}$ for 24 hours with a jar fermentor (21, working volume 1.51). The bacterial cells were then removed from the culture broth by centrifugation, and supernatant $n$-as used as the enzyme source.

\section{Assay of protease activity}

The proteolytic activity was assayed by the method of Long etal. (1981) with slight modification. Azocasein (Sigma) was used as substrate at a concentration of $1 \%$ in $0.05 \mathrm{M}$ potassium phosphate buffer $(\mathrm{pH} 7.5)$. A $0.5 \mathrm{ml}$ of enzyme solution n-as added to $1 \mathrm{ml}$ of substrate solution and the mixture was incubated at $70^{\circ} \mathrm{C}$ for $10 \mathrm{~min}$. The reaction was terminated by the addition of $10 \%$ trichloroacetic acid. After standing at $4^{\circ} \mathrm{C}$ for $10 \mathrm{~min}$. the mixture was filtrated and $1 \mathrm{ml}$ of $0.4 \mathrm{M} \mathrm{NaOH}$ was added to $1 \mathrm{ml}$ of the filtrate. The absorbance of this mixture was measured at $440 \mathrm{~nm}$. One unit of protease activity was defined as amount of enzyme that gave an increase in absorbance of 0.1 at $440 \mathrm{~nm}$ in above condition.

\section{Purification of the protease}

Next 4 steps of purifications were performed at a cold room at 4 C. Step 1: acetone precipitation: two volumes of cold acetone $\left(-20^{\circ} \mathrm{C}\right)$ was slowly added into the culture supernatant with gentle stirring. The mixture was allowed to stand overnight in a cold room, afterwhich the precipiate foemed was collected by centrifugation. The precipitate $\mathrm{n}$-as then dissolved with a portion of $10 \mathrm{mM}$ potassium phosphate buffer (pH 6.8) and dialyzed against the same buffer. Step 2: hydroxylapatite chromatography: the dialysate (crude enzyme solution) was charged on a column of hydroxylapatite (Nacalai Tesque) which previously equilibrated with $10 \mathrm{mM}$ potassium phosphate buffer $(\mathrm{pH} \mathrm{6.8)}$. After the column was washed with the same buffer, the enzyme adsorbed was eluted with $80 \mathrm{mM}$ potassium phosphate buffer ( $\mathrm{pH}$ 6.8). The fractions with major protease activity were collected and dialyzed against 50mM Tris- $\mathrm{HCl}(\mathrm{pH} 7.5)$. Step 3: DEAE-Sephadex A-50 chromatography: the dialysate was then charged on a column of DEAE-Sephadex A-50 (Pharmacia) which previously equilibrated with $50 \mathrm{mM}$ Tris- $\mathrm{HCl}(\mathrm{pH} 7.5)$. After the column was washed with the same buffer, the enzyme adsorbed was eluted with a linear gradient of $0-0.5 \mathrm{M} \mathrm{NaCl}$ in the same buffer. The fractions with major protease activity n-ere collected again and concentrated by ultrafiltration with a membrane filter (10kDa molecular weight cut-off, Advantec). Step 4: Sephadex G - 75 superfine gel filtration: the concentrate was then charged on a column of Sephadex G-75 superfine (Pharmacia) which had been equilibrated with 50mM potassium phosphate buffer ( $\mathrm{pH} 7.5)$. The protease active fractions through the column was collected as the purified BSP2 protease. The BSP2 was stored in the frozen state at $-20{ }^{\circ} \mathrm{C}$ until use.

\section{Protein determination}

Protein concentration was determined using a protein assay kit (Bio-Rad Chemical 
Division, Calif, USA) with bovine serum albumin as a standard protein.

\section{SDS-polyacrylamide gel electrophoresis}

Homogeneity of BSP2 was examined by SDS-PAGE on a slab gel containing $12.5 \%$ of polyacrylamide and $5 \%$ of 2 - mercaptoethanol (Nacalai Tesque). Molecular weight of BSP2 was also determined by comparing its mobility with following standard proteins. The standard proteins used were phospholylase b $(94 \mathrm{kDa})$, bovine serum albumin $(67 \mathrm{kDa})$, carbonic anhydrase $(30 \mathrm{kDa})$, trypsin inhibitor $(20.1 \mathrm{kDa})$ and $\alpha$-lactalbumin (14.4kDa). The proteins were stained with coomassie brilliant blue $\mathrm{R}-250$.

\section{Effect of inhibitors on the proteolytic activity of the protease}

The effect of some protease inhibitors on the activity of the protease was examined in the following method. The BSP2 solution was mixed with each inhibitor solution at a final concentration of $1 \mathrm{mM}$. After standing at room temperature for $30 \mathrm{~min}$, remaining activity was assayed.

\section{Hydrolysis of various proteins}

Various proteins including casein, lysozyme, haemoglobin, collagen, elastin, keratin and fibrinogen were used as substrate. The reaction was carried out at $70^{\circ} \mathrm{C}$ for $20 \mathrm{~min}$. The amount of extricated amino acids by the reaction was determined by the method of Yemm and Cocking (15) as glycine standard.

\section{NH,-terminal amino acid sequence of the protease}

The $\mathrm{NH}_{2}$-terminal amino acid sequence of the purified enzyme was determined using an Applied Biosystems (Foster City, Calif, USA) Protein/Peptide Sequencer, Model 473A. Identification of phenylthiohydantoin derivatives of amino acids was performed in an Applied Biosystem PTH analyser model 610A system.

\section{RESULTS AND DISCUSSION}

\section{Purification of the protease}

The BSP2 from the strain No. 2 was purified as shown in Table 1 which summarizes major purification steps. The specific activity of purified BSP2 was 46.3 folds higher than that of culture supernatant with a recovery of $8.2 \%$. Figure 1 shows the result of final gel chromatogram (step 4). Figure 2 shows the homogeneity of the BSP2 by SDS-PAGE wirh some standard proteins. From Fig. 2, the BSP2 gave a molecular weight of $35 \mathrm{kDa}$.

Table 1. Summary of purification.

\begin{tabular}{|c|c|c|c|c|c|}
\hline Purification step & $\begin{array}{c}\text { Volume } \\
\text { (ml) }\end{array}$ & $\begin{array}{c}\text { Total } \\
\text { activity } \\
\text { (U) }\end{array}$ & $\begin{array}{c}\text { Total } \\
\text { protein } \\
\text { (mg) }\end{array}$ & $\begin{array}{l}\text { Specific } \\
\text { activity } \\
(\mathrm{U} / \mathrm{mg})\end{array}$ & $\begin{array}{c}\text { Recovery } \\
(\%)\end{array}$ \\
\hline Culture supernatant & 1930 & 695 & 272.2 & 2.5 & 100 \\
\hline Acetone precipitation & 150 & 537 & 108.3 & 5.0 & 77.3 \\
\hline Hydroxylapatite & 76 & 195 & 16.9 & 11.6 & 28.1 \\
\hline DEAE-Sephadex A-50 & 69 & 157 & 2.3 & 67.5 & 22.6 \\
\hline Sephadex G-75 superfine & 17 & 57 & 0.5 & 115.8 & 8.2 \\
\hline
\end{tabular}




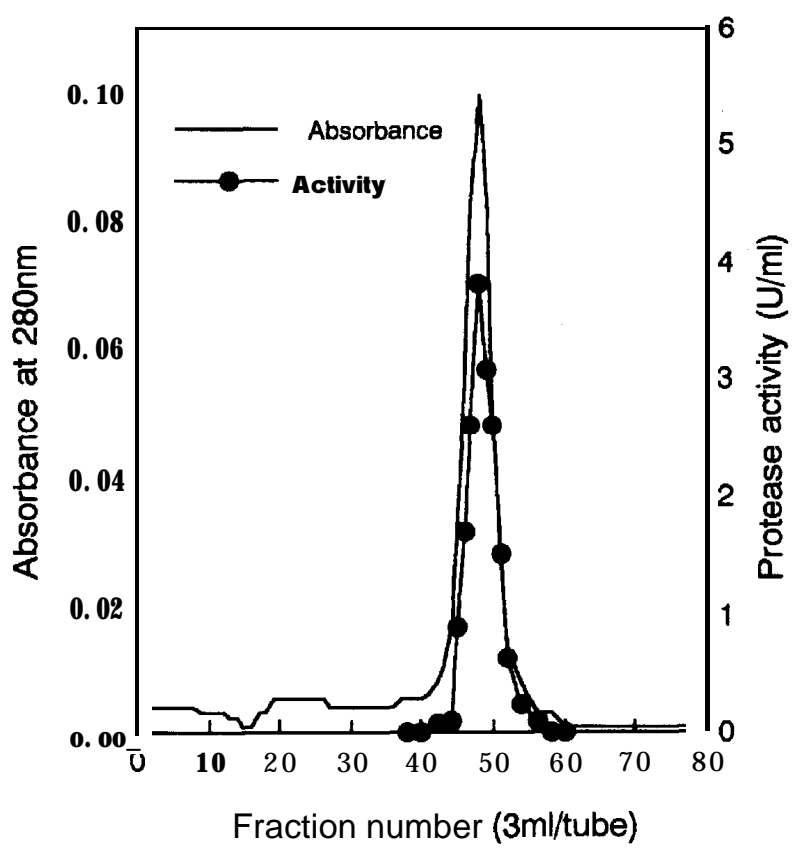

Fig. 1. Elution profile of Sephadex G-75 superfine.

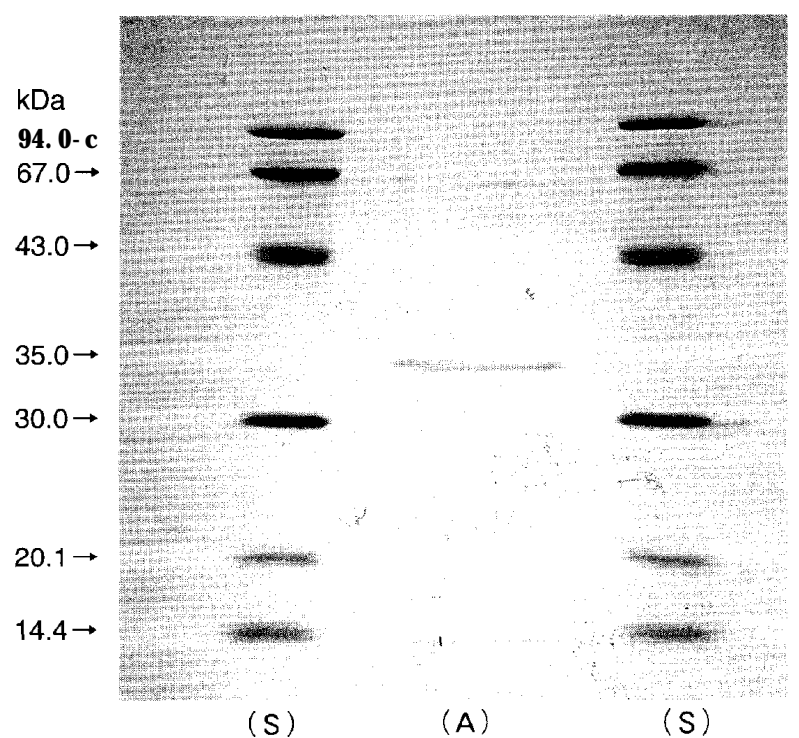

Fig. 2. SDS-PAGE (slab, $12.5 \%$ gel) of purified protease from B. stearothermophilus No. 2.

A; Purified protease

S; Standard proteins (Electrophoresis caliburation kit, Pharmacia). 94.0 kDa (phosphorylase b), 67.0 kDa (bovine serum albumin), 43.0 $\mathrm{kDa}$ (ovalbumin), $30.0 \mathrm{kDa}$ (carbonic anhydrase), $20.1 \mathrm{kDa}$ (trypsin inhibitor), $14.4 \mathrm{kDa}$ ( $\alpha$-lactalbumin) 
Effect of pH on the proteolytic activity and stability of the protease

Figure 3 shows the optimum $\mathrm{pH}$ for proteolytic: activity of thr BSP2. The optimum pH was 7.5 - 8.0 and no change observed in the presence or absence of $\mathrm{CaCl}$. Figure 4 shows that the $\mathrm{BSP} 2$ was almost, stable in the $\mathrm{pH}$ range of $6-11.5$ after treatment at $4^{\circ} \mathrm{C}$ for 24 hours. The pHstability was not affected whether with or without $\mathrm{CaCl}_{\text {s. }}$.

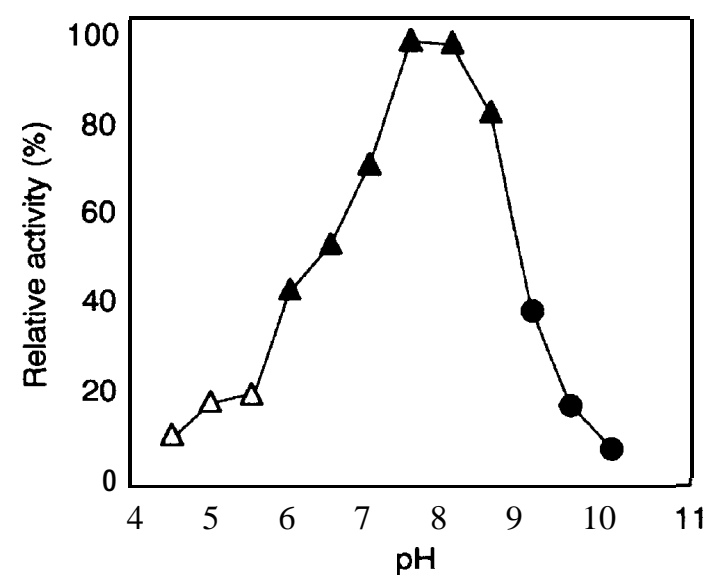

Fig. 3. Effect of $\mathrm{pH}$ on the proteolytic activity of protease from B.stectollhemoplitus No. 2. The reaction was carried out at $70^{\circ} \mathrm{C}$ in the following buffers; acetate (A), phosphate (A) and carbonate

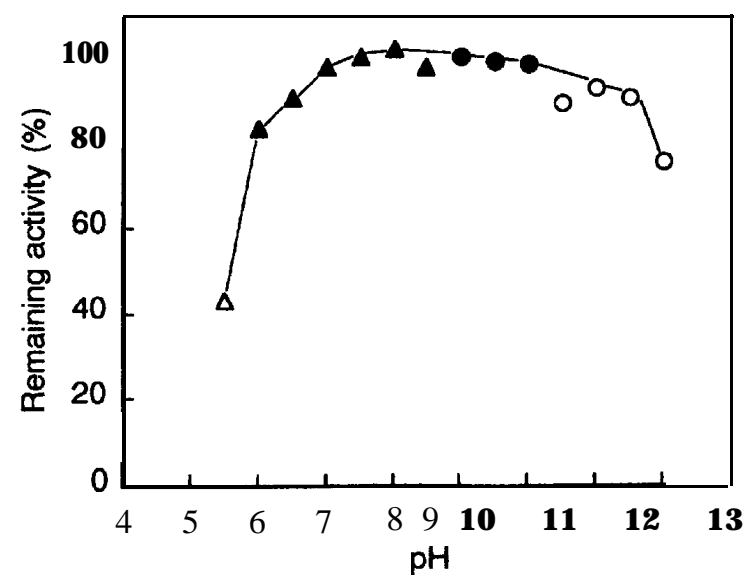

Fig. 4. Effect of $\mathrm{pH}$ on the stability of protease from $B$. stearothermophilus No. 2.

The $\mathrm{pH}$ treatment was carried out at $4^{\circ} \mathrm{C}$ for $24 \mathrm{hr}$ in the following buffers: acetate (A), phosphate (A), carbonate $(O)$ and sodium phosphate $\mathrm{NaOH}(\mathrm{O})$. 


\section{Effect of temperature on the proteolytic activity and stability of the protease}

Figure 5 shows the effect of temperature on the proteolytic activity of the BSP2. The optimum temperature for the proteolytic activity was $75^{\circ} \mathrm{C}$ in the presence of $5 \mathrm{mM} \mathrm{CaCl}$. Figure 6 shows the temperature dependency of the BSP2. The effect of temperature on the stability of the $\mathrm{BSP} 2$ was examined at $90^{\circ} \mathrm{C}$ in the presence or absence of $\mathrm{CaCl}_{2}$. In the presence of $\mathrm{CaCl}_{2}$, optimum temperature was estimated to be at $90 \mathrm{C}$, while the optimum temperature was sifted down to $70^{\circ} \mathrm{C}$ in absence of $\mathrm{CaCl}_{2}$. Even after the treatment at $90^{\circ} \mathrm{C}$ for $80 \mathrm{~min}$, more than $60 \%$ of original activity was remained in the presence of $\mathrm{CaCl}_{2}$. As in many reports related to metalloñprotease, calcium ion seemed markedly to increase the stability of the protease.

\section{Effect of inhibitors on the proteolytic activity of the protease}

Table 2 shows the effect of inhibitors on the proteolytic activity of BSP2. Metal chelaters such as EDTA or EGTA almost completely inactivated the activity of BSP2. Although IAA showed some effect on the activity, this might be the result of which IAA reacted with side groups of a number of amino acids (Gundlach et al., 1959). Therefore, NSP2 from strain No. 2 may be classified to a metallo-protease.

In view point of the effects of inhibitors and optimum $\mathrm{pH}$, the BSP2 from strain No.2 is clearly classified as an neutral protease. Most of microbial neutral proteases are metal cherater sensitive and showed no or a little inhibition toward other inhibitors (McConn et al., 1964).

\section{Hydrolysis of various proteins}

Table 3 shows the hydrolysis of various proteins by BSP2 including some insoluble

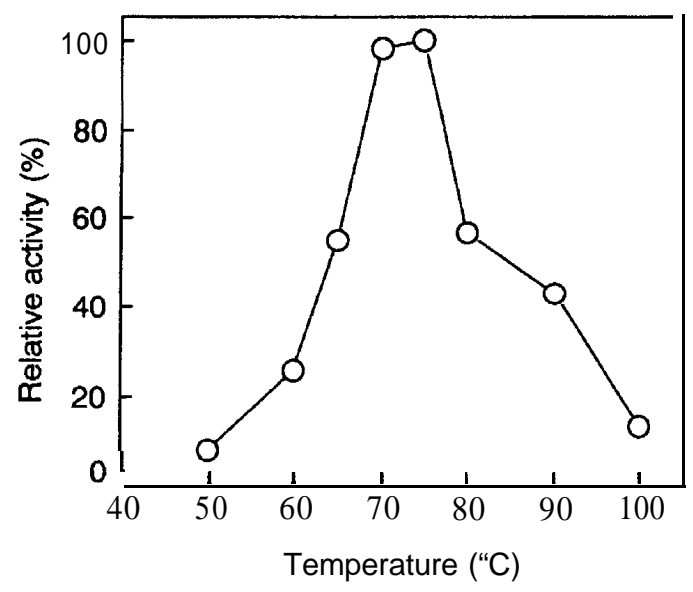

Fig. 5. Effect of temperature on the proteolytic activity of protease from B. stearothermophilus No. 2. in the presence of $5 \mathrm{mM} \mathrm{CaCl}$.

The enzyme activity was assayed at the indicated temperature in the presence of $5 \mathrm{mM}$ $\mathrm{CaCl}_{\text {. }}$. 


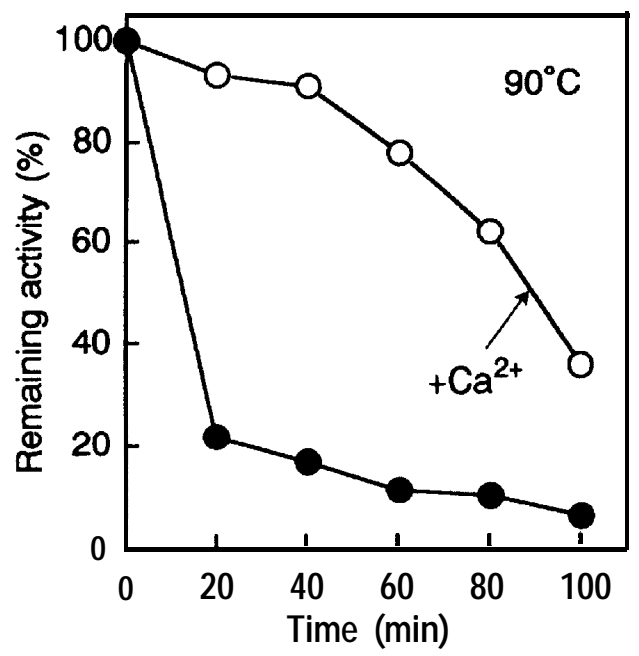

Fig. 6. Effect of temperature on the stability of protease from B. stearothermophilus No. 2. After incubation at $90{ }^{\circ} \mathrm{C}$ for the indicated times in the presence $(\mathrm{O})$ or absence of $5 \mathrm{mM} \mathrm{CaCl}$, the remaining activity was assayed.

Table 2. Effect of inhibitor on the proteolytic activity protease.

\begin{tabular}{lr}
$\begin{array}{c}\text { Inhibitor } \\
(\mathrm{mM})\end{array}$ & $\begin{array}{c}\text { Remaining activity } \\
(\%)\end{array}$ \\
\hline None & 100 \\
EDTA(1) & 7 \\
EGTA(1) & 0 \\
IAA(1) & 58 \\
PMSF(1) & 97 \\
\hline
\end{tabular}

EDTA, ethylenediaminetetraacetic acid; EGTA, ethylene glycol bis ( $\beta$-aminoethylether) $-\mathrm{N}, \mathrm{N}$, N', N'-tetraacetic acid; IAA, iodoacetic acid; PMSF, phenylmethylsulphonyl fluoride

proteins. Among them, the highest degree of hydrolysis was observed in casein. In the insoluble proteins, such as collagen, elastin and haemoglobin (the latter precipitated rapidly at $70^{\circ} \mathrm{C}$ ) were hydrolyzed a little amount while keratin and fibrinogen were not hydrolyzed at all. Although the strain No.2 was isolated from sewage sludge compost, this neutral protease, BSP2, may be a little contribution to decompose sewage sludge.

NH,-terminal amino acid sequence of the protease 
Table 3. Hydrolysis of various proteins by protease.

\begin{tabular}{lc}
\hline Substrate & $\begin{array}{c}\text { Proteolytic activity } \\
\text { ( } \mu \text { g glycine/ml) }\end{array}$ \\
\hline Casein & 53.2 \\
Lysozyme & 31.5 \\
Haemoglobin & 10.5 \\
Collagen & 9.6 \\
Elastin & 9.3 \\
Keratin & 0 \\
Fibrinogen & 0 \\
\hline
\end{tabular}

The reaction was carried out at $70^{\circ} \mathrm{C}$ for $20 \mathrm{~min}$.

Et. stearothermophilus No. 2

3. caldolyticus 12)

B. stearothermophilus CU21 ${ }^{18)}$

B. stearothermophilus $\mathbf{M K 2 3 2} 2^{11)}$

B. thermoproteolyticus ${ }^{6}$ )
1

10
19

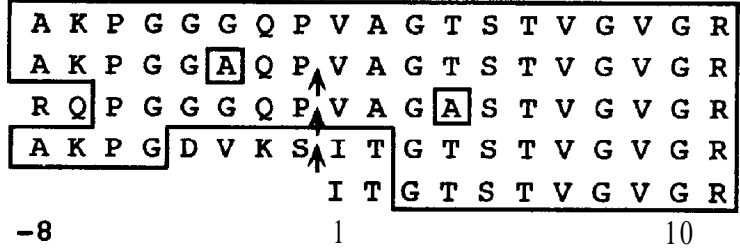

Fig. 7. NH,-terminal amino acid sequence of protease (BSP2) from strain No. 2 and its comparison with neutral proteases from Bacillus strains.

Amino acids identical to those of BSP2 from strain No. 2 (Bacillus stearothermophilus No. 2) are boxed. Amino acid sequences of proteases from Bacilluscaldolyticus, Bacillus stearothermophilus CLJ21 and MK232 were deduced from their nucleotide sequences. Arrows indicate the maturation sites.

The NH,-terminal amino acid sequence of BSP2 was determined. Figure 7 shows the comparison with those of thermostable neutral proteases from reffered Bacillus strains (Titani et al., 1972; Kubo and Imanaka, 1988a; Van Der Burg et al., 1991; Takagi et al., 1985). The amino acid sequence of the first 19 residues from NH,-terminus of protease from the strain No. 2 showed extremely high homology with those from -8 to 11 of the neutral proteases from refered Bacillus strains. Although the significance of the excess eight amino acid residues of the BSP2 was not clear, they seemed not to participate in the function of catalysis of the protease.

\section{REFERENCES}

Endo, S. 1962 Studies on protease produced by thermophilic bacteria. Hakko-Kogaku, 40: 346-353

Fujio, Y. and S. Kume 1991 Isolation and identification of thermophilic bacteria from sewage sludge compost. J.Fermnt. Bioeng., 72: 334-337 
Gundlach, G., W.H. Stein anc S. Moore 1959 The nature of the amino acid residues involved in the inactivation of ribonuclease by idoacetone. J.Biol.Chem., 234: 1754-1 760

Heinen, U.J. and W.Heinen 1972 Characteristics and properties of a caldoiiactive bacterium producing extracellular enzymes and two related strains. Arch.Mikrobiol., 82: 1-23

Kester, W.R. and B.W. Matthews 1977 Comparison of the structures of carboxypeptidase A and thermolysin. J.Biol. Chem., 252: 7704-7710

Kubo, M. and T. Imanaka 1988a Cloning and nucleotide sequence of the highly thermostable neutral protease gene from Bacillus stearothermohilus.J.Gen. Microbiol., 134: 1883-1892

Kuho, hl., K. Murayama, K. Seto and T. Imanaka 1988b Highly thermostable neutral protease from Bacillus stearothermophitus. J. Ferment. Technol., 66: 13-17

Latt, S.A., B. Holmquist and B.L. Valee 1969 Thermolysis; a Zinc metalloenzyme. Biochem. Biophys., Res. Commun., 37: 3X-339

Long, S., M.A.Mothibeli, F.T. Robb and D.R. Woods 1981 Regulation of extracellular protease activity by histidine in a collagenolytic Vibrio alginolyticus strain.J.Gen., Microbiol., 127: 193-199

Matthews, B.W., J.N. Jansonius, P.M. Colman, B.P. Schoenborn and D. Dupourque 1972a Threedimentional structure of thermolysin. Nature Neu Hid., 238: 37-41

Matthews, B.W., P.M. Colman, J.N.Jansonius, K. Titani, K.A. Walsh and H. Neurath 1972b Structure of thermolgsin. Nature New Biol., 238: 41-43

McCom, D., D. Tsuru and K. Yasunobu 1964 Bacillus subtilis neutral proteases; a zincenzyme of high specific activity. J.Biol.chem., 239: 3706-3715

Morihara, K and H. Tsuzuki 1970 Kinetic study with oligopeptides. Eur.J.Biochem., 15: 374-380

Stauffer, $\quad \mathrm{pH} \quad$ Arch.Biochem. biophys., 147: 568-570

Takagi, M., T. Imanaka and S. Aiba 1985 Nucleotide sequence and promoter region for the neutral protease gene from Bacillus stearothemophilus.J.Bacteriol., 163: 824-831

Titani, K., MA. Hermodoson, L.H. Ericsson, K.A. Walsh and H. Neurath 1972 Amino-acid sequence of thermolysin. Nature New Biol., 238: 35-37

Van Der Burg, B., H.G. Enequist, M.E. Van Der Haar, V.G. Eijsink, B.K. Stulp and G. Venema 1991 A highly thermostable neutral protease from Bacillusculdolyticus; cloning and expression of the gene in Bacillus subtilis and characterization of the gene product. J.Bacteriol., 173: 4107-4115

Yemm, E.M. and E.C. Cocking 1955 The determination of amino-acids with ninhydrin. Analyst, 80:209213 